\title{
Natural infection in ovarian structures by bovine herpesvirus 1: molecular and serological detection
}

\section{Infecção natural em estruturas ovarianas pelo Herpesvírus bovino 1: detecção molecular e sorológica}

\author{
Emílio César Martins Pereira ${ }^{1 *}$; Eduardo Paulino da Costa ${ }^{2}$; Abelardo Silva Júnior ${ }^{2}$; \\ Vívian Rachel de Araújo Mendes ${ }^{3}$; Giancarlo Magalhães dos Santos ${ }^{4}$; \\ Sanely Lourenço da Costa ${ }^{3}$; Marcus Rebouças Santos ${ }^{3}$
}

\begin{abstract}
In this study, the polymerase chain reaction (PCR) was used to evaluate the presence of viral DNA in ovarian tissue, in the cumulus-oocyte complex (COC), follicular liquid, and blood of animals naturally infected with bovine herpesvirus-1 (BoHV-1). The serum profile of the sampled animals was also evaluated. Samples of serum, blood, ovarian tissue, follicular liquid, and COC were collected from 147 slaughterhouse animals that were not vaccinated against BoHV-1. Contaminated or insufficient samples were disregarded. Serological tests allowed the identification of serum-positive animals with neutralizing antibodies against BoHV-1. Analysis of samples by PCR revealed the presence of viral DNA in $0.9 \%(1 / 115)$ of the COC samples, in $4.3 \%$ (5/117) of the ovarian tissue samples, and in $2.8 \%$ (3/108) of the blood samples. Viral DNA was not detected in any of the follicular liquid samples. In serological samples, a positivity of 83.6\% (117/140) was observed for BoHV-1. All PCR-positive animals, regardless of the samples analyzed, showed positivity in the serum neutralization test for the detection of BoHV-1-specific antibodies. According to these results, a high prevalence of antibodies against BoHV-1 was detected in naturally infected animals from different herds, and the molecular tests revealed the presence of viral DNA in bovine ovarian tissue, providing evidence that this might be a site of BoHV-1 infection in naturally infected animals.
\end{abstract}

Key words: Bovine herpesvirus, infectious bovine rhinotracheitis, cumulus-oocyte complex, ovarian tissue

\section{Resumo}

Neste trabalho foi avaliada a presença do DNA viral, por meio da Reação em Cadeia da Polimerase (PCR), no tecido ovariano, nos oócitos, líquido folicular e sangue de vacas naturalmente infectadas. Também foi avaliado o perfil sorológico dos animais amostrados. Foram coletadas amostras de soro, sangue, tecido ovariano, líquido folicular e complexo cumulus-oócitos de 147 animais abatidos em frigorífico não vacinados contra o herpesvirus bovino 1 (BoHV-1). Amostras tóxicas ou insuficientes foram descartadas. Os testes sorológicos foram realizados permitindo a identificação dos animais soropositivos para anticorpos neutralizantes contra o BoHV-1. Foram realizadas as PCRs onde foi observada a presença do DNA viral em $0,9 \%$ (1/115) dos oócitos, em 4,3\% (5/117) do tecido ovariano e em 2,8\% (3/108) do sangue. Em nenhuma das amostras de líquido folicular foi detectado o DNA viral. Nas amostras sorológicas observou-se 83,6\% (117/140) de positividade para o BoHV-1. Dentre

1 Discente, Universidade Federal de Viçosa, UFV, Viçosa, MG, Brasil. E-mail: emiliovet2004@yahoo.com.br

2 Profs., UFV, Viçosa, MG, Brasil. E-mail: epcosta@ufv.br; asjvet@hotmail.com

3 Discentes, UFV, Viçosa, MG, Brasil. E-mail: vramendes@hotmail.com; sanelylc@hotmail.com; marcusrsantos@yahoo.com.br

4 Prof., Faculdade de Ciências Biológicas e da Saúde, UNIVIÇOSA, Viçosa, MG, Brasil. E-mail: gianmagalhaes@hotmail.com Author for correspondence 
os animais positivos na PCR, independente das amostras, todos apresentavam positividade no teste de soroneutralização para detecção de anticorpos para BoHV-1. Conclui-se que em animais de diferentes rebanhos analisados foi detectada alta prevalência de anticorpos contra o BoHV-1 e que nos testes moleculares houve a presença do DNA viral em amostras de tecidos ovarianos de bovinos, evidenciando que estas estruturas poderiam ser sítios de infecção pelo vírus em animais naturalmente infectados.

Palavras-chave: Herpesvírus bovino, rinotraqueíte infeciosa bovina, oócitos, tecido ovariano

\section{Introduction}

Brazil, considered a pioneer in reproductive biotechnologies, is well known for its bovine embryo research. It is internationally distinguished with respect to its active in vitro production and exportation of the embryos of this species (VIANA et al., 2010).

The trade of embryos is considered an efficient and safe method for transportation of genetic material, as correct certification procedures can prevent the dissemination of reproductive illnesses (GARD et al., 2007). The probable sources of embryonic infection during in vitro production (IVP) include oocytes, spermatozoa, serum, and cell culture media (PERRY, 2005). These issues are of interest to researchers seeking to understand the mechanisms underlying interactions between infectious organisms and gametes and embryos.

The bovine herpesvirus 1 (BoHV-1), a member of the Herpesviridae family, causes reproductive problems in herds and has been associated with contamination of oocytes and embryos (MARLEY et al., 2008a). The presence of the virus harms the cumulus-oocyte complex (COC), which leads to a decrease in fecundation rates during IVP of embryos (GUERIN et al., 1990).

Themolecularmethods availableforidentification of pathogens in embryos and gametes meet the diagnostic testing requirements of sensitivity, speed, and specificity. Among these methods, polymerase chain reaction (PCR) is considered to be fast and sensitive for detection of BoHV-1 in both male and female gametes (EDENS et al., 2003; TAKIUCHI et al., 2003, 2005; MARLEY et al., 2008a, b). The great advantage of this technique is that it is based on the identification of the viral genome; therefore, it does not require the presence of viable viral particles (HAYDEN et al., 1991; BÉLAK; BALLAGI-PORDÁNY, 1993). A nonlethal method to evaluate the presence of pathogens in embryos before their transfer to receivers is currently not available (RUFINO et al., 2006).

To further understand the effects of BoHV-1 infection on reproduction, the present study was carried out to identify the presence of BoHV-1 DNA in blood and ovarian structures, including the follicular liquid, ovarian tissue, and COC of naturally infected bovines. The presence of neutralizing antibodies against BoHV-1 in serum was also determined.

\section{Materials and methods}

The protocol relevant to the described experiments was submitted and approved by the Ethical Committee of the Department of Veterinary Medicine of Universidade Federal de Viçosa. Its registration was confirmed on March 29, 2009.

All samples were collected from animals of monitored properties where herd vaccination against BoHV-1 was not practiced. These animals did not show apparent clinical symptoms of the disease (e.g., a mucopurulent nasal discharge).

Blood samples and ovaries were collected during bleeding and evisceration of the animals, respectively. Whole blood was collected in glass tubes treated with anticoagulant heparin. Serum was separated by centrifuging the blood samples at $710 \mathrm{~g}$ for $10 \mathrm{~min}$ and then labeled appropriately in Eppendorf tubes and stored at $-20^{\circ} \mathrm{C}$ until further use. Following sample collection, the presence of 
neutralizing antibodies was determined according to the methodology proposed by the "Manual of Standards for Diagnostic Tests and Vaccines" (OIE, 2008), and the samples were separated into two groups, i.e., serum-positive and serum-negative animals.

Ovaries were collected and individually stored in sterile plastic containers. The samples were stored in a thermal box at $\sim 4^{\circ} \mathrm{C}$ and transported to the laboratory within a maximum period of $2 \mathrm{~h}$ following collection.

Aliquots of follicular liquid, $\mathrm{COC}$, ovarian tissue, and blood obtained from 147 animals were evaluated. For this procedure, the ovaries of each animal were punctured with $25 \times 7$-gauge disposable needles. First, the follicular liquid of the largest follicle was aspirated and centrifuged at 600 $g$ for $20 \mathrm{~min}$ to separate the follicular liquid from the cells completely. Aspiration of the remaining ovarian follicles provided $\mathrm{COC}$ aliquots. After aspiration, COC aliquots were washed by three successive passages in microdrops of autoclaved ultrapure water and then frozen in water in sterile microtubes. Samples of the ovarian tissue were obtained via transverse cuts, using a surgical bistoury individualized for each sample, deepening until the vascular region.

After the complete processing of the samples, fragments of the ovarian tissue, follicular liquid, COCs, and blood samples obtained from each animal were identified and stored at $-20^{\circ} \mathrm{C}$ until analysis in the molecular biology laboratory, where the detection of the viral DNA was accomplished by PCR.

Total DNA was extracted from the samples using a SV Wizard Genomic kit, according to the manufacturer's protocol (Promega, Madison, WI, USA).

PCR and the sequence of oligonucleotides were accomplished as described by Takiuchi et al. (2005), using a total volume of $25 \mu 1$. The oligonucleotides used were P3 (sense): 5'
GCTGTGGGAAGCGGTACG3'(nt351-368)andP4 (anti-sense): 5' GTCGACTATGGCCTTGTGTGC $3^{\prime}$ (nt 817-796), designed to amplify a 468-base pair (bp) fragment of the BoHV-1 $g D$ gene. PCR was performed in a solution containing $2.5 \mathrm{ml}$ of extracted DNA and $22.5 \mathrm{ml}$ of PCR mix containing 10 pmol of each primer, $1.5 \mathrm{mM}$ of dNTP (Promega), 1.5 units of recombinant Taq DNA polymerase (Phoneutria, Belo Horizonte, Brazil), 1× PCR buffer $(100 \mathrm{mM}$ Tris-HCl pH 8.4, $500 \mathrm{mM} \mathrm{KCl}$, $1 \%$ Triton $\mathrm{X}-100,1.5 \mathrm{mM} \mathrm{MgCl}$ ), and autoclaved ultrapure water, resulting in a final volume of 25 $\mathrm{mL}$. After preparation, the solution was transferred to a thermocycler (PTC-100, MJC Inc., Marietta, GA, USA). The reaction cycle was as follows: one step of 4 min at $94^{\circ} \mathrm{C}$, followed by 40 cycles of 1 $\min$ at $94^{\circ} \mathrm{C}, 1 \mathrm{~min}$ at $60^{\circ} \mathrm{C}$, and $1 \mathrm{~min}$ at $72^{\circ} \mathrm{C}$, and a final extension stage of $7 \mathrm{~min}$ at $72^{\circ} \mathrm{C}$. The amplified products were stored at $-4^{\circ} \mathrm{C}$ or analyzed immediately.

For observation of the amplifications, $5 \mu 1$ aliquots of the amplified products were subjected to electrophoresis in a $1 \%$ agarose gel, diluted in

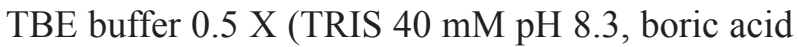
$45 \mathrm{mM}$, EDTA $1 \mathrm{mM}$ ) under constant voltage of $90 \mathrm{~V}$ for $\sim 45 \mathrm{~min}$. Gels were stained with GelRed (Uniscience, São Paulo, Brazil) and observed under UV light. For comparison of the amplified fragments (products), 100-bp standard marker ladders were used.

The qualitative variables were compared in contingency tables and analyzed by chi-square test at a $5 \%$ probability level (SAMPAIO, 2002).

\section{Results and Discussion}

In this study, the rate of serum-positive animals was $83.6 \%$ (117/140). The evaluation of BoHV-1 DNA via PCR was accomplished in samples of the ovarian tissue, blood, follicular liquid, and COC. However, the number of samples evaluated for each group was different, due to technical difficulties during collection. Specifically, collection of COC 
and follicular liquid were impossible in ovaries of animals in anestrous.

As shown in Table 1, viral DNA was found in almost all ovarian structures of the serum-positive animals, except for follicular liquid (Figure 1).
There were no significant differences $(\mathrm{P}>0.05)$ between the results obtained from samples of serum-positive and serum-negative animals. Within the serum-negative group, no viral DNA was found in the analyzed samples.

Table 1. Polymerase chain reaction (PCR)-based detection of viral DNA in ovarian structures and blood obtained from BoHV-1 serum-positive and serum-negative animals.

\begin{tabular}{cccc}
\hline Samples & $\begin{array}{c}\text { PCR-Positive in serum- } \\
\text { positive animals }\end{array}$ & $\begin{array}{c}\text { PCR-Positive in serum- } \\
\text { negative animals }\end{array}$ & Total number of animals \\
\hline Cumulus-oocyte & $1 / 115(0.9 \%)$ & $0 / 29(0.0 \%)$ & 144 \\
complex & $0 / 114(0.0 \%)$ & $0 / 29(0.0 \%)$ & 143 \\
Folicular liquid & $5 / 117(4.3 \%)$ & $0 / 30(0.0 \%)$ & 147 \\
Ovarian tissue & $3 / 108(2.8 \%)$ & $0 / 27(0.0 \%)$ & 135 \\
Blood & & & \\
\hline
\end{tabular}

Figure 1. Visualization of PCR products in 1\% agarose gel, demonstrating the detection of BoHV-1 DNA in blood and ovarian structures. [C+: Positive Control; C-: Negative Control; M: 100-bp molecular size marker; Lanes 1, 2, and 3 (Positive Samples); 1 (cumulus-oocyte complex sample), 2 (ovary tissue sample), and 3 (blood sample); Lanes 4, 5, and 6 (Negative Samples)].

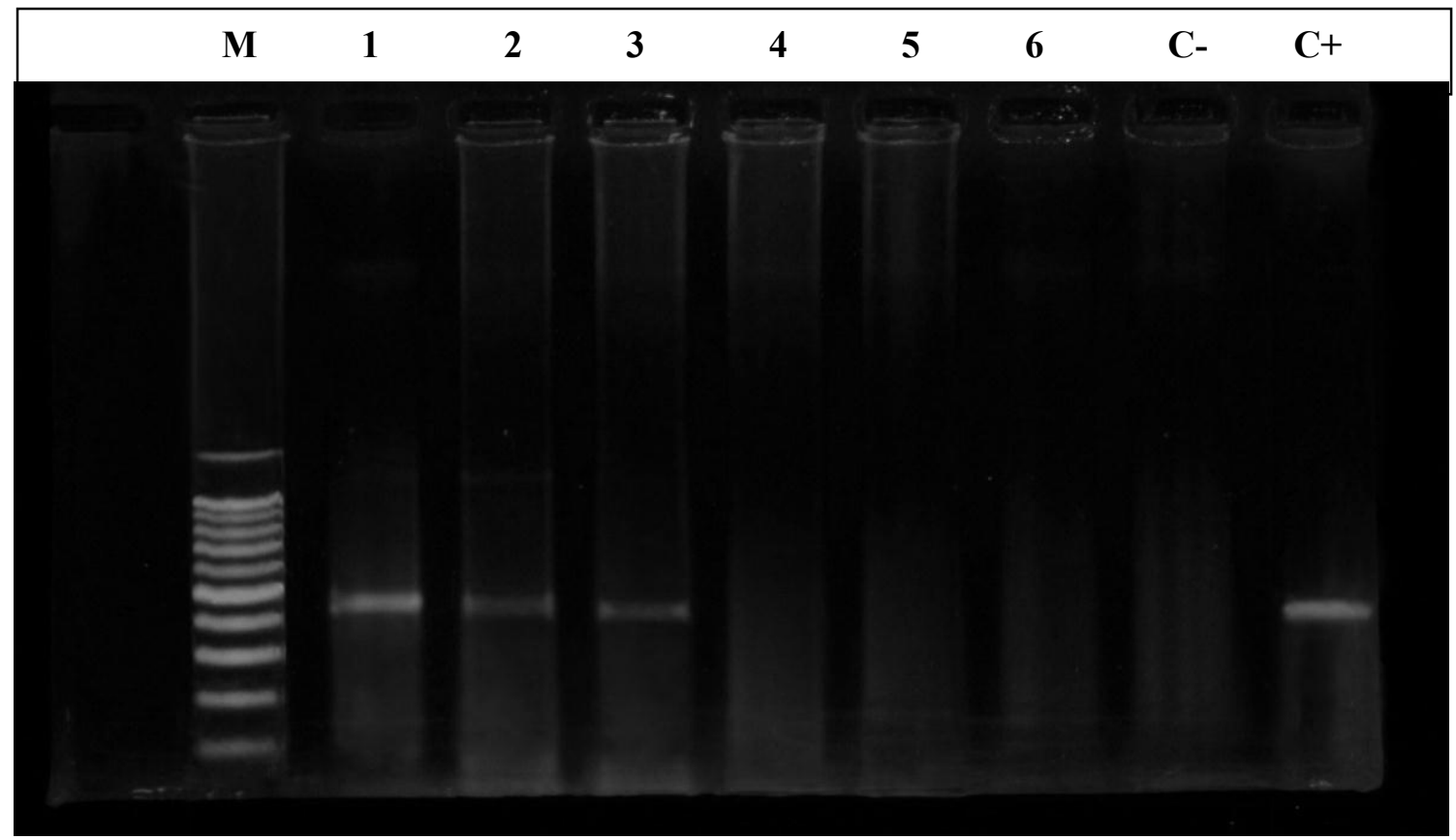

Molecular tests, especially PCR, are considered sensitive, fast, and practical. The PCR technique is widely used for evaluation of gametes and reproductive structures (MAHAJAN et al., 2013). These tests have been shown to efficiently detect
BoHV-1 and were successfully used in samples that are similar to those evaluated in the present study, such as bovine oocytes (BIELANSKI et al., 1997), follicular liquid (MARLEY et al., 2008b; D'ANGELO et al., 2009), blood (FUCHS et al., 
1999), and ovarian tissue (VAN ENGELENBURG et al., 1995; MWEENE et al., 1996). However, the majority of those studies were performed on experimentally infected animals or samples infected in vitro; thus, the analyzed samples differed significantly from those collected from the naturally infected animals evaluated in this study. Specifically, when the study group was confined to experimentally infected animals, the researcher was sure that the viral load in the analyzed samples would be high and more easily detected by diagnostic tests, thereby guaranteeing the success of those methods. In the present study, the animals were randomly selected; therefore, any positive samples evaluated were the result of natural infection. Thus, significantly fewer positive samples might have been identified in the present study because the viral load in naturally infected samples might be lower than that in experimentally infected samples.

In the present study, the low frequency of the viral DNA in COC and its absence in the follicular liquid agree with the results obtained by Oliveira (2007), who verified that animals that are serologically positive for BoHV-1 had virus-negative $\mathrm{COC}$ and suggested that follicular liquids collected from serum-positive animals that presented no clinical symptoms of the disease might be irrelevant. However, detection of viral DNA in a COC sample evaluated in the present study suggests that the possibility of transmission of BoHV-1 through the COC should be seriously considered.

Another hypothesis for the low detection frequency of viral DNA in the animals evaluated in the present study could be the latency mechanism of the BoHV-1 virus. Viral latency can occur following initial infection with a field sample or a vaccine sample. During the course of clinical and subclinical infections, BoHV-1 disseminates along the nerves until it arrives at the trigeminal ganglion, where the viral DNA remains latent (WINKLER et al., 2000). In support of this, Cortez et al. (2006) detected the presence of BoHV-1 DNA in only $2.4 \%$ of samples isolated from both lung and brain macerates. Additionally, Mweene et al. (1996) were able to identify the latency sites of the virus in experimentally infected animals, as DNA was isolated and amplified from the trigeminal ganglion, ovary, lung, nasal and tracheal mucosal membranes, spleen, and leucocytes taken from prescapular and pre-crural lymphatic nodules. The presence of BoHV-1 was also detected by PCR at additional locations associated with latency, such as lymph nodes and nasal mucous membranes (VAN ENGELENBURG et al., 1995). However, there is no report of viral DNA detection in ovarian structures of naturally infected animals, which would likely be in a latent state of infection, an experimental situation similar to that encountered in this study.

Although serology was performed in this study, it has not been shown to be effective for detection of latent infection in animals (GIBBS, RWEYEMANN, 1977; STRAUB, 1990). It is believed that a better method to detect latent infection, especially in calves with maternal antibodies, is the late hypersensitivity test (NANDI et al., 2009). Viral DNA can also be detected by in situ hybridization in the nucleus of local sensory ganglions (ACKERMANN; WYLER, 1984). However, these tests were not performed in the present study. Therefore, the low frequency of viral DNA detection in ovarian structures, either in serum-positive or serum-negative animals, is most likely due to latency of BoHV-1.

The presence of BoHV-1 in ovarian tissue and COC detected in this study reaffirms the hypothesis of infection by this virus in female reproductive organs. This result strongly suggests the possibility that BoHV-1 interferes with bovine reproduction. However, it should be noted that Muylkens et al. (2007) reported a lack of molecular bases that support BoHV-1 tropism in epithelial cells of bovine female genitalia.

\section{Conclusions}

The presence of the BoHV-1 was determined in samples of ovarian tissue, $\mathrm{COC}$, and blood analyzed 
by PCR. The results obtained confirm the presence of this virus in ovarian structures of naturally infected bovines.

\section{Acknowledgements}

The authors wish to express sincere gratitude to CNPq and FAPEMIG for their financial support for this work.

\section{References}

ACKERMANN, M.; WYLER, R. The DNA of an IPV strain of bovine herpesvirus 1 in sacral ganglia during latency after intravaginal infection. Veterinary Microbiology, Amsterdam, v. 9, n. 1, p. 53-63, 1984.

BÉLAK, S.; BALLAGI-PORDÁNY, A. Application of the polymerase chain reaction (PCR) in veterinary diagnostic virology. Veterinary Research Communications, Dordrecht, v. 17, n. 1, p. 55-72, 1993.

BIELANSKI, A.; LUTZE-WALLACE, C.; SAPP, T.; JORDAN, L. The efficacy of trypsin for disinfection of in vitro fertilized bovine embryos exposed to bovine herpesvirus 1. Animal Reproduction Science, Philadelphia, v. 47, n. 1-2, p. 1-8, 1997.

CORTEZ, A.; CASTRO, A. M. G.; HEINEMANN, M. B.; SOARES, R. M.; LEITE, R. C.; SCARCELLI, E.; GENOVEZ, M. E.; ALFIERI, A. A.; RICHTZENHAIN, L. J. Detecção de ácidos nucléicos de Brucella spp., Leptospira spp., herpesvirus bovino e vírus da diarréia viral bovina, em fetos bovinos abortados e em animais mortos no perinatal. Arquivo Brasileiro de Medicina Veterinária e Zootecnia, Belo Horizonte, v. 58, n. 6, p. 1226-1228, 2006.

D'ANGELO, M.; VISINTIN, J. A.; RICHTZENHAIN, L. J.; GONÇALVES, R. F. Evaluation of trypsin treatment on the inactivation of bovine herpesvirus type 1 in vitro produced preimplantation embryos. Reproduction in Domestic Animals, Malden, v. 44, n. 3, p. 536-539, 2009.

EDENS, M. S. D.; GALIK, P. K.; RIDDELL, K. P.; GIVENS, M. D.; STRINGFELLOW, D. A.; LOSKUTOFF, N. M. Bovine herpesvirus-1 associated with single, trypsin-treated embryos was not infective for uterine tubal cells. Theriogenology, New York, v. 60, n. 8, p. 1495-1504, 2003.

FUCHS, M.; HÜBERT, P.; DETTERER, J.; RZIHA, H. J. Detection of bovine herpesvirus type 1 in blood from naturally infected cattle by using a sensitive PCR that discriminates between wild-Type virus and virus lacking glycoprotein E. Journal of Clinical Microbiology, Washington, v. 37, n. 8, p. 2498-2507, 1999.

GARD, J. A.; GIVENS, M. D.; STRINGFELLOW, D. A. Bovine viral diarrhea virus (BVDV): Epidemiologic concerns relative to semen and embryos. Theriogenology, New York, v. 68, n. 3, p. 434-442, 2007.

GIBBS, E. P. J.; RWEYEMANN, M. M. Bovine herpesviruses. Part I. Bovine herpesvirus 1. Vetennary Bulletin, London, v. 47, n. 5, p. 317-343, 1977.

GUERIN, B.; Le GUIENNE, B.; ALLEITTA, M.; HARLAY, T.; THIBIER, M. Effets de la contamination par le BHV-1 sur la maturation et fecundation in vitro des ovocytes des bovines. Recueil Médecine Vétérinaire, Paris, v. 66, n. 1, p. 911-917, 1990.

HAYDEN, J. D.; HO, S. A.; HAWEKY, P. M.; TAYLER, G. R.; QUIRE, P. The promises and pitfalls of PCR. Reviews in Medical Microbiology, London, v. 22, n. 2, p. 129-137, 1991.

MAHAJAN, V.; BANGA, H. S.; DEKA, D.; FILIA, G.; GUPTA, A. Comparison of diagnostic tests for diagnosis of infectious bovine rhinotracheitis in natural cases of bovine abortion. Journal of Comparative Pathology, Oxford, v. 149, n. 4, p. 391-401, 2013.

MARLEY, M. S. D.; GIVENS, M. D.; GALIK, P. K.; RIDDELL, K. P.; LOONEY, C. R.; STRINGFELLOW, D. A. Efficacy of a recombinant trypsin product against bovine herpesvirus 1 associated with in vivo- and in vitro-derived bovine embryos. Theriogenology, New York, v. 69, n. 6, p. 746-757, 2008a.

MARLEY, M. S. D.; GIVENS, M. D.; GALIK, P. K.; RIDDELL, K. P.; STRINGFELLOW, D. A. Development of a duplex quantitative polymerase chain reaction assay for detection of bovine herpesvirus 1 and bovine viral diarrhea virus in bovine follicular fluid. Theriogenology, New York, v. 70, n. 2, p. 153-160, 2008 b.

MUYLKENS, B.; THIRY, J.; KIRTEN, P.; SCHYNTS, F.; THIRY, E. Bovine herpesvirus 1 infection and infectious bovine rhinotracheitis. Veterinary Research, London, v. 38, n. 2, p. 181-209, 2007.

MWEENE, A. S.; OKAZAKI, K.; KIDA, H. Detection of viral genome in non-neural tissues of cattle experimentally infected with bovine herpesvirus 1 . The Japanese Journal of Veterinary Research, Sapporo, v. 44, n. 3, p. 165-174, 1996.

NANDI, S.; MANOJ KUMAR, M.; CHAUHAN, R. S. Bovine herpes virus infections in cattle. Animal Health Research Reviews, Cambridge, v. 10, n. 1, p. 85-98, 2009. 
OFFICE INTERNATIONAL DES EPIZOOTIES - OIE. Terrestrial animal health code. World organization for animal health. 2003, 2005 e 2008. Paris: Copyright, 2008. Available at: <http://www.oie.int.>. Accessed at: 30 fev. 2014.

OLIVEIRA, A. P. Pesquisa do vírus da rinotraquite infecciosa dos bovinos em complexos cumulus-oócito e líquido folicular. 2007. Dissertação (Mestrado em Medicina Veterinária) - Universidade Federal de Minas Gerais, Belo Horizonte.

PERRY, G. H. Analyzing disease transmission risks from abattoir-derived in vitro-produced bovine embryos (Abstract). Reproduction, Fertility and Development, Collingwood, v. 17, n. 1-2, p. 244, 2005.

RUFINO, F. A.; SENEDA, M. M.; ALFIERI, A. A. Impacto do Herpesvírus bovino 1 e do vírus da diarreia viral bovina na transferência de embriões. Archives of Veterinary Science, Curitiba, v. 11, n. 1, p. 78-84, 2006.

SAMPAIO, I. B. M. Estatística aplicada à experimentação animal. Belo Horizonte: Fundação de Ensino e Pesquisa em Medicina Veterinária e Zootecnia, 2002. 265 p.

STRAUB, O. C. Infectious bovine rhinotracheitis virus. In: DINTER, Z; MORUN, B. Virus Infectious of ruminants. Amsterdam: Elsevier Science Publishers, 1990. p. 71-108.
TAKIUCHI, E.; MÉDICI, K. C.; ALFIERI, A. F.; ALFIERI, A. A. Bovine herpesvirus type 1 abortions detected by a semi nested-PCR in Brazilian cattle herds. Research in Veterinary Science, Londres, v. 79, n. 1, p. 85-88, 2005.

TAKIUCHI, E.; MÉDICI, K. C.; ALFIERI, A. F.; ALFIERI, A. A. Otimização da reação em cadeia pela polimerase (seminested PCR) para a detecção do herpesvírus bovino tipo 1 em fragmentos de órgãos fetais e em sêmen de bovinos naturalmente infectados. Semina: Ciências Agrárias, Londrina, v. 24, n. 1, p. 43-56, 2003.

VAN ENGELENBURG, F. A.; KAASHOEK, M. J.; VAN OIRSCHOT, J. T.; RIJSEWIJK, F. A. A glycoprotein E deletion mutant of bovine herpesvirus 1 infects the same limited number of tissues in calves as wild-type virus, but for a shorter period. Journal of General Virology, Londres, v. 76, n. 9, p. 2387-2392, 1995.

VIANA, J. H. M.; SIQUEIRA, L. G. B.; PALHÃO, M. P.; CAMARGO, L. S. A. Use of in vitro fertilization technique in the last decade and its effect on Brazilian embryo industry and animal production. Acta Scientiae Veterinariae, Porto Alegre, v. 38, n. 2, p. 661-674, 2010.

WINKLER, M. T.; DOSTER, A.; JONES, C. Persistence and reactivation of bovine herpesvirus 1 in the tonsils of latently infected calves. Journal of Virology, Washington, v. 74, n. 11, p. 5337-5346, 2000. 
